\title{
Autumn-applied Growth Regulators Influence Leaf Retention, Bud Hardiness, Bud and Flower Size, and Endodormancy in Peach and Cherry
}

\author{
Schuyler D. Seeley, Hossein Damavandy ${ }^{1}$, and J. LaMar Anderson \\ Department of Plants, Soils, and Biometeorology, Utah State University, Logan, UT 84322-4820 \\ Richard Renquist \\ Orchard Mesa Research Center, Colorado State University, 3168 B1/22 Road, Grand Junction, \\ CO 81503
}

\author{
Nancy W. Callan \\ Western Agricultural Research Center, Montana State University, Montana Agricultural Experiment \\ Station, 580 Quast Lane, Corvallis, MT 59828 \\ Additional index words. Prunus persica, P. cerasus, leaf pull force, chlorophyll, xanthophyll, dormancy
}

\begin{abstract}
Foliar applications of growth regulators (GR) in early autumn induced leaf retention (LR) on peach [Prunu,s persica (L.) Batsch.] and 'Montmorency' tart cherry (Prunus cerasus L.) trees. In 'Johnson Elberta' peach, the relative effectiveness of GRs on LR was NAA = Promalin $\left(\mathbf{B A}+\mathbf{G A}_{4+7}\right)>\mathbf{G A}_{4+7}>\mathbf{G A}_{3}>\mathbf{B A}>$ control, and on leaf detachment pull force $(\mathrm{PF}) \mathrm{NAA}>\mathbf{B A}+\mathbf{G A}_{4+7}>\mathbf{G A}_{4+7}=\mathbf{G A}_{3}>\mathbf{B A}>\mathbf{B A}>$ control. Relative GR-induced chlorophyll (CL) content in retained leaves was $\mathbf{B A}+\mathbf{G A}_{4+7}>\mathbf{G A}_{4+7}>\mathbf{G A}_{3}>\mathbf{B A}>$ control $>$ NAA. Relative xanthophyll (XN) content of retained leaves was $\mathrm{NAA}>$ control $>\mathrm{BA}>\mathbf{G A}_{3}=\mathbf{G A}_{4+7}=\mathbf{B A}+\mathbf{G A}_{4+7}$. Treating only half of a peach tree with NAA did not affect LR on the untreated side. NAA decreased subsequent bud and flower size in peach. Bud hardiness was enhanced by NAA in 'Johnson Elberta' peach but not in 'Redhaven' peach or in 'Montmorency' tart cherry. NAA increased hardening on both the leafy treated (foliated) and untreated (defoliated) sides of half-treated 'Johnson Elberta' trees. Increased endodormancy duration, as measured by $\mathrm{GA}_{3}$ forcing of terminal leaf buds, was proportional to LR. Chemical names used: $N$-(phenylmethyl)- $1 \mathrm{H}-$ purin6-amine (BA); (1a,2ß,4bß,10ß)-2,4a,7-trihydroxy-l-methyl-8-methylenegibb-3-ene-1,1O-dicarboxylic acid,l,4alactone $\left(\mathbf{G A}_{3}, \mathbf{G A}_{4+7}\right)$; l-naphthaleneacetic acid (NAA).
\end{abstract}

Trees of deciduous fruit species begin to develop cold hardiness in late summer after shoots stop growing. Vegetative maturity (Nissila and Fuchigami, 1978), with its associated internally controlled reduction in water content, follows shoot growth cessation. Winter bud scales form from leaf petiole bases and senescing leaves fall. These changes reduce plant surface area and water requirement.

Leaves provide substrate; receive signals inducing hardening processes, and promote hardiness development in the late growing season. Those leaves that harden, survive, and remain active after the first freeze continue to be the source of a translocatable cold-hardiness promoter (Fuchigami et al., 1971). Defoliation of peach trees in late summer decreases subsequent flower bud hardiness (Walser, 1975). Holubowicz (1982) determined that the youngest leaves were the most active in promoting hardiness development. Cultural or chemical treatments that would delay senescence during the critical autumn hardening period could increase winter hardiness of flower buds.

Plant GRs affect leaf senescence and subsequent bud development. Auxin maintains protein levels and delays senescence in leaves of Prunus and other species (Osborne and Hallaway, 1960, 1964). Late-summer auxin applications subsequently delay spring bud development in peach trees (Hitchcock and Zim-

Received for publication 29 Apr. 1991. Accepted for publication 12 Nov. 1991. This report is based, in part, upon research conducted and supported as a part of SAES Western Regional Project W-130. Utah Agr. Expt. Sta. J. Paper no. 4024. Mention of a trademark or proprietary product does not imply endorsement or constitute a guarantee or warranty. The cost of publishing this paper was defrayed in part by the payment of page charges. Under postal regulations, this paper therefore must be hereby marked advertisement solely to indicate this fact.

'Current address: 2355 Weymouth Lane, Crofton, MD 21114. merman, 1943), and gibberellins applied in late summer or early autumn increase flower bud hardiness in peach (Edgerton, 1966; Proebsting and Mills, 1964) but decrease hardiness in sweet cherry (Proebsting and Mills, 1974). Cytokinins delay leaf senescence (Thimann, 1980). Ethylene production by leaves has negligible effect on their senescence (Thimann, 1980), but ethylene applications may delay leaf senescence (Gianfagna et al., 1986) and increase hardiness of flower buds (Proebsting and Mills, 1976).

The objectives of this study were to determine the effects of several GRs on leaf senescence and retention in the autumn and the effect of this extended period of autumn leaf activity on subsequent flower bud hardiness and endodormancy development in peach and tart cherry trees.

\section{Materials and Methods}

GR sprays were applied with hand sprayers to drip $\approx 1$ month before normal leaf fall (15 Oct.-1 Nov.); details of experiments in three states are in Table 1. Three to five tree replications were used in completely randomized designs. NAA, $\mathrm{GA}_{3}$, and BA were obtained from Aldrich Chemical Co., Milwaukee, Wis.; NAA 200 from Rhône-Poulenc, Research Triangle Park, N. C.; gibberellins $\mathrm{A}_{4}$ and $\mathrm{A}_{7}\left(\mathrm{GA}_{4+7}\right)$ from Imperial Chemical Co., Bracknell Berks, England; and $\mathrm{BA}+\mathrm{GA}_{4+7}$ (Promalin) from Abbott Laboratories, North Chicago. Triton X-77 (Rohm and Haas, Philadelphia) surfactant was used in 1982-83, Regulaid (Kale, Inc. Overland Park, Kan.) in subsequent years. NAA

Abbreviations: CL, chlorophyll; CO, Colorado; GR, growth regulator; LR, leaf retention; MT, Montana; PF, leaf detachment pull force; UT, Utah; XN, xanthophyll. 
Table 1. GR treatments applied to peach and cherry to delay leaf abscission.

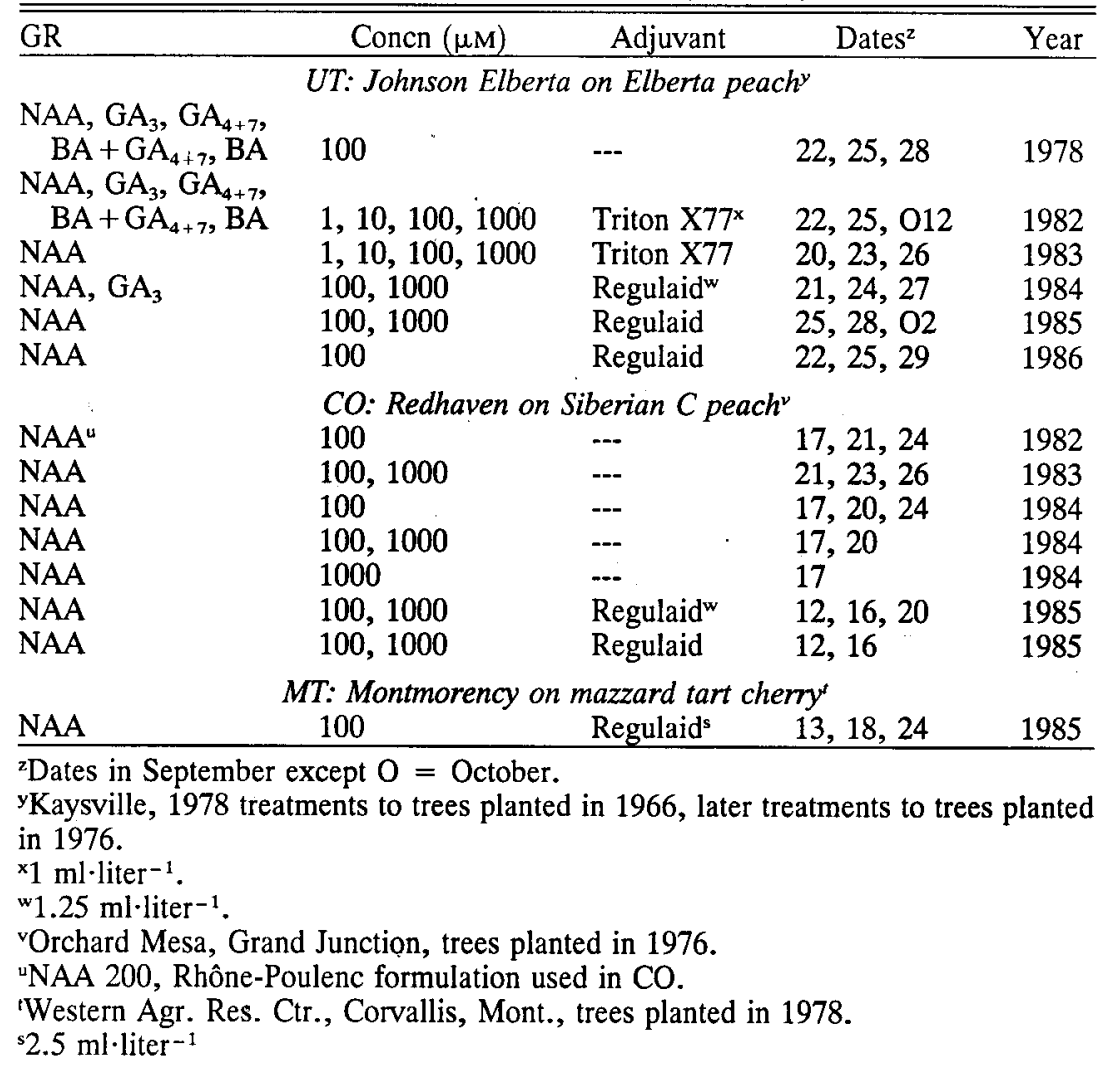

sprays or spray solution without NAA were applied to one side of 'Johnson Elberta' peach trees to determine translocation effects. Polyethylene barriers were placed through the tree to avoid drift and runoff contamination on the untreated side.

Effects of the treatments on leaf senescence were measured by LR, PF, and CL and XN concentrations. LR, expressed as leaves per centimeter of shoot length, was measured by counting the leaves remaining on three randomly selected shoots per tree on five trees taken at 1.8- to 2.2-m elevation in the tree. PF was determined on 10 to 30 leaves from each tree of each treatment until differences were observed, then on 50 to 60 leaves per tree with an Ametek Hunter spring mechanical force gauge model L-1OOO (Ametek, Hatfield, Pa.) in UT, an Ametek LKG1 in MT, and an Effegi Dynamometer (Effegi, Alfonsine, Italy) in CO. A small clamp or rubber-covered clothespin was placed on the leaf, attached to the PF gauge, and pulled parallel to the leaf axis. CL was measured from leaves collected 21 days after the last GR application. CL was extracted from 2-g leaf lamina samples from each of three trees per treatment with $500 \mathrm{ml}$ of $90 \%$ aqueous acetone and estimated from spectrophotometer readings at 663 and $645 \mathrm{~nm}$ (Bruinsma, 1963). XN (Butt and Lamb, 1981) was extracted from similar samples with $500 \mathrm{ml}$ of hexane/acetone, 9:1 v/v, and read at $475 \mathrm{~nm}$.

Flower bud hardiness was determined in freezing chambers in UT. and CO and after natural freezes in MT. The chamber temperature fall was $1 \mathrm{C} / \mathrm{h}$. Time and temperature were recorded with a Honeywell Servoline 45 (Ft. Washington, Pa.). Analyses to determine of the temperature that would kill $50 \%$ of the flower buds $\left(\mathrm{T}_{50}\right)$ was performed on individual trees for up to eight treatments on each date. Thirty to 40 twigs, 20 to $40 \mathrm{~cm}$ long, were taken from each tree, and divided into five twig samples. The starting temperature was $-3 \mathrm{C}$. At designated times and temperatures, bundles of shoots were retrieved from the chamber automatically. Samples were retrieved manually in CO. After being exposed to various freezing temperatures, peach shoots in the UT and CO studies were held at room temperature in a moist environment for $24 \mathrm{~h}$. Flower buds were sectioned longitudinally to determine floral mortality. Injury to florets of tart cherry in MT was determined at the end of winter before damaging spring temperatures had occurred and again after critical temperatures occurred in spring. On 14 Mar. 1986, all buds from three 20 -cm-long twigs per tree, $\approx 1.5 \mathrm{~m}$ from the ground, were dissected to determine number of injured and uninjured flowers. On 13 Apr. 1986, temperatures in MT dropped to $-6.8 \mathrm{C}$. That afternoon, four twigs per tree, one each from north, south, east, and west exposures, were collected, and sound and injured pistils were counted.

To determine effects of defoliation of trees under fall conditions on subsequent cold hardiness, three 'Johnson Elberta' peach trees were defoliated by hand on 1 Sept. 1982. No shoots grew subsequently. Flower bud hardiness was measured at 2week intervals thereafter until 1 Dec.

Length and width of flower buds and isolated flowers from NAA- and $\mathrm{GA}_{3}$-treated and control 'Johnson Elberta' peach trees in UT were measured with a binocular microscope eyepiece micrometer. Ten buds were selected at random from three shoots of each of three trees per treatment and measured on $19 \mathrm{Dec}$. 1984. Buds were cut transversely just above the base, and a teasing needle was used to separate the scales and release the flower for measurement.

Endodormancy intensity of shoot terminal leaf buds in UT was determined by the amount of terminal bud growth resulting after twigs (five replications of three per treatment) were removed from the tree periphery at a 1.8- to 2.2-m height, soaked 
for $1 \mathrm{~h}$ in $\mathrm{GA}_{3}$ solutions $\left(5,30,100,300\right.$, and $\left.500 \mathrm{mg} \cdot \mathrm{liter}^{-1}\right)$, and placed in a growth chamber under a $16-\mathrm{h}$ photoperiod (10C night/22C day). Observations of terminal leaf buds were made twice weekly. Endodormancy was considered terminated when the forcing effect of gibberellin was no longer evident (Hatch and Walker, 1969).

\section{Results}

\section{Leaf senescence}

$L R$ and $P F$. Growth promoters significantly increased peach leaf retention (Table 2$)$. PF was correlated with LR $\left(r^{2}=0.969\right)$. GR-induced $(100 \mu \mathrm{M}) \mathrm{LR}$ decreased in the order: NAA = $\mathrm{BA}+\mathrm{GA}_{4+7}>\mathrm{GA}_{4+7}>\mathrm{GA}_{3}>\mathrm{BA}>$ control. $\mathrm{PF}$ decreased in response to growth promoters $(100 \mu \mathrm{M})$ in about the same way: $\mathrm{NAA}>\mathrm{BA}+\mathrm{GA}_{4+7}>\mathrm{GA}_{4+7}=\mathrm{GA}_{3}>\mathrm{BA}>$ control. Ethephon (250 $\mu$ l.liter ${ }^{-1}$, applied only in MT on 'Montmorency' tart cherry, significantly increased leaf fall (data not shown). A typical time course for leaf fall on NAA-treated peach trees and controls is shown in Fig. 1. Leaf fall was delayed on peach trees at all sites. NAA-induced LR extended into December after a third application in UT on 12 Oct. 1982.

LR was dose dependent with the greatest increase occurring between 10 and $100 \mu \mathrm{M}$ (Fig. 2). Polynomial orthogonal comparisons indicated that the linear component explained most of the relationship between LR and log NAA concentration. The cubic component was also highly significant. PF changed most rapidIy between 1 and $10 \mu \mathrm{M}$ NAA and approached the maximum near $100 \mu \mathrm{M}$ (Fig. 2). Polynomial orthogonal comparisons followed by residual analysis indicated that the' best curve fit for PF in relation to NAA concentration was linear with quadratic and cubic components also significant at $P=0.0001$ and 0.0010 , respectively. NAA delayed senescence more than GA or BA based on PF and LR (Table 2).

NAA-induced peach LR was localized on the sprayed portion of the tree (Table 2). LR on the untreated and treated sides was not significantly different from control and whole treated trees, respectively.

Leaf pigment changes. CL content of GR-retained peach leaves was in the following order: $\mathrm{BA}+\mathrm{GA}_{4+7}>\mathrm{GA}_{4+7}>\mathrm{GA}_{3}>$ $\mathrm{BA}>$ control $>$ NAA (Table 2). XN concentration was highest in the NAA-treated leaves and varied inversely with CL con-

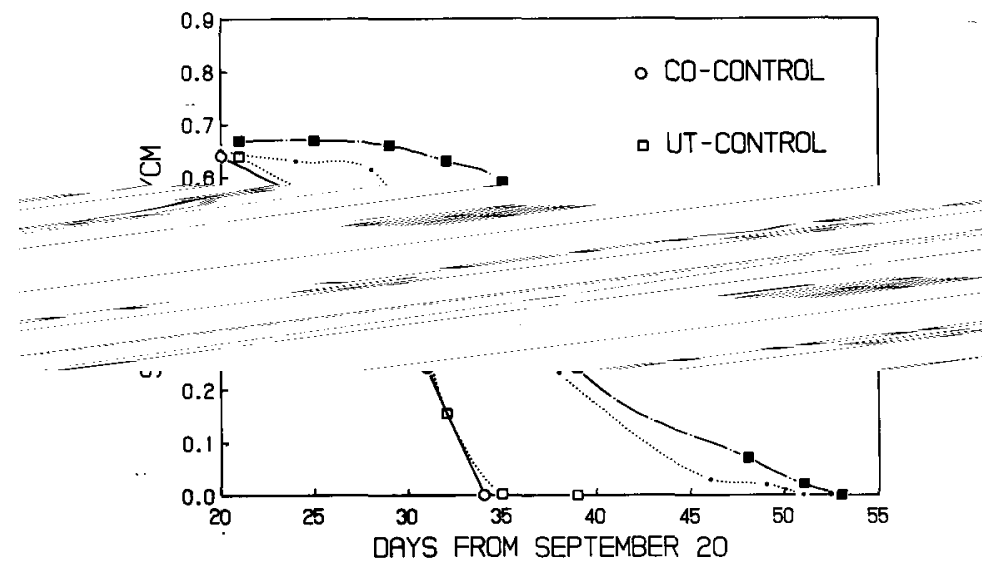

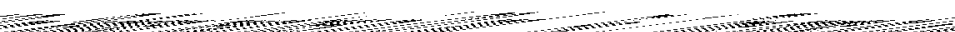

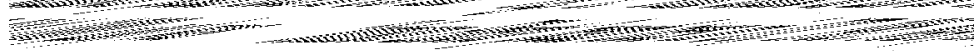

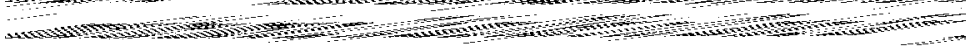
Win I Uct. untl all leaves nad abscised.

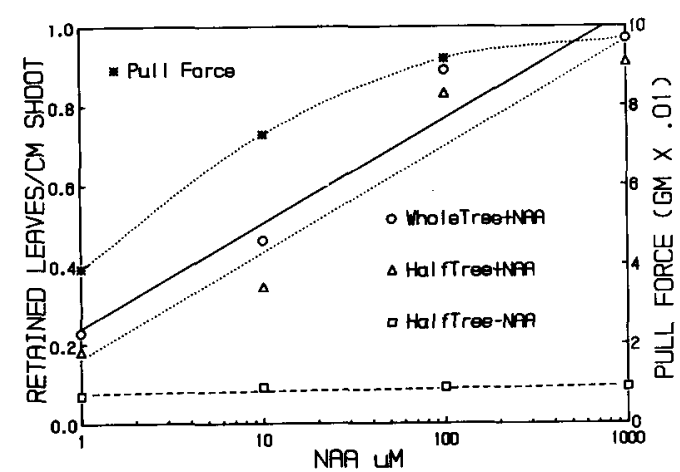

Fig. 2. LR and PF on 21 Oct. 1982 on 'Johnson Elberta' peach trees. LR on entire-treated trees (WholeTree +NAA), $Y=0.24+$ $0.26 \log (\mathrm{x}), r^{2}=0.92$; half-treated trees, treated side, (HalfTree + NAA), $\mathrm{Y}=0.19+0.26 \mathrm{Log}(\mathrm{x}), r^{2}=0.92$; and half-treated trees, untreated-side (HalfTree-NAA), $Y=0.08+0.007 \log (\mathrm{x})$, $r^{2}=0.22$; and PF (entire-treated trees), $Y=387+128.4 \log (\mathrm{x})$ $+161 \log \left(x^{2}\right)-46.4 \log \left(x^{3}\right), r^{2}=0.995$, in response to 1 to 1000 $\mu \mathrm{M}\left(10^{-6}\right.$ to $\left.10^{-3} \mathrm{M}\right) \mathrm{NAA}$ treatments $(22,25$ Sept.; 12 Oct.) 1982 . Control LR $=0.06 / \mathrm{cm}$. Control PF $=235 \mathrm{~g}$.

centration: NAA $>$ control $>\mathrm{BA}>\mathrm{GA}_{3}=\mathrm{GA}_{4+7}=$ $\mathrm{BA}+\mathrm{GA}_{4+7} \cdot \mathrm{GA}, \mathrm{BA}$, and $\mathrm{BA}+\mathrm{GA}_{4+7}$ prolonged $\mathrm{LR}$ and $\mathrm{CL}$ retention. NAA treatment also prolonged LR with the leaves having high carotenoid levels but reduced CL content.

Few leaves $(<0.06 / \mathrm{cm})$ were present on control trees at the time of the pigment measurements. Leaf CL decreased and XN increased as NAA concentration increased. The largest change occurred between 10 and $100 \mu \mathrm{M}$ NAA. The curve for chlorophyll was almost linear between 10 and $1000 \mu$ MAA while the curve for xanthophyll was sigmoid between 1 to $1000 \mu \mathrm{M}$ NAA (data not shown). Saturation of the system with NAA occurred at a level $(100 \mu \mathrm{M})$ somewhat higher than endogenous levels measured by traditional auxin bioassay systems; however, endogenous measurements were not taken to determine auxin penetration. If NAA penetration was $1 \%$ to $10 \%$, then saturation of peach leaf responses would be about the same as found in some bioassays for auxins in stems (Leopold, 1955).

\section{Effects on flower bud hardiness}

NAA. Hardiness of 'Johnson Elberta' peach flower buds was increased by NAA. Hardiness differences between the control and $100 \mu \mathrm{M}$ NAA-treated flowers averaged $2.6 \mathrm{C}$ in seven tests in Winter and Spring 1982-83 (Table 3). Sixteen hardiness determinations in the winters of 6 years $(1978-79,1982-83,1983-$ $84,1984-85,1985-86$, and 1986-87) indicated greater cold hardiness in flower buds of NAA-treated 'Johnson Elberta' trees, whereas three tests indicated no significant hardiness differences (Table 3). The average hardiness increase measured in all late fall and winter tests was $2.2 \mathrm{C}$.

Defoliation. Hardening of 'Johnson Elberta' peach flower buds in late summer was delayed by defoliation (Table 3). Differences in hardiness through September and October were significant; however, later differences were not.

Translocation. 'Johnson Elberta' flower buds from both sides of split-tree treatments that defoliated normally on the untreated side and retained leaves on the NAA-sprayed side had equal cold hardiness on 23 Nov. 1983 (Table 4). Buds from both sides were significantly hardier than buds from the treated side of control trees that were sprayed on one side with solution lacking NAA.

Species, cultivar, and location. Hardiness of flower buds of 
Table 2. Effect of early autumn applications of GR on indicators of leaf senescence of 'Johnson Elberta' peach (UT, 1982).

\begin{tabular}{|c|c|c|c|c|c|c|}
\hline \multirow[b]{2}{*}{$\begin{array}{l}G^{2} \\
(100 \mu M)\end{array}$} & \multicolumn{3}{|c|}{$\begin{array}{c}\mathrm{LR}^{\mathrm{y}} \\
\text { (leaves } / \mathrm{cm} \text { ) }\end{array}$} & \multirow[b]{2}{*}{$\begin{array}{l}\mathrm{PFy} \\
\text { (g) }\end{array}$} & \multirow[b]{2}{*}{$\begin{array}{c}\mathrm{CL}^{\mathrm{x}} \\
\left(\mathrm{mg} \cdot \mathrm{g}^{-1}\right. \\
\text { fresh wt) }\end{array}$} & \multirow[b]{2}{*}{$\begin{array}{c}\mathrm{XN}^{\mathrm{x}} \\
\left(\mathrm{mg} \cdot \mathrm{g}^{-1}\right. \\
\text { fresh wt) }\end{array}$} \\
\hline & $\begin{array}{c}\text { Whole } \\
\text { tree }\end{array}$ & $\begin{array}{l}\text { Half- } \\
\text { tree } \\
\text { trtd }\end{array}$ & $\begin{array}{c}\begin{array}{c}\text { Half- } \\
\text { tree } \\
\text { untrtd }\end{array} \\
\end{array}$ & & & \\
\hline Control & $0.09 \mathrm{a}^{\mathrm{w}}$ & $0.07 \mathrm{a}$ & $0.08 \mathrm{a}$ & $198 \mathrm{a}$ & $30.2 \mathrm{e}$ & $0.68 \mathrm{~b}$ \\
\hline BA & $0.21 \mathrm{~b}$ & $0.26 \mathrm{~b}$ & $0.08 \mathrm{a}$ & $566 \mathrm{~b}$ & $33.1 \mathrm{~d}$ & $0.57 \mathrm{c}$ \\
\hline $\mathrm{GA}_{3}$ & $0.52 \mathrm{c}$ & $0.54 \mathrm{c}$ & $0.07 \mathrm{a}$ & $731 \mathrm{c}$ & $39.2 \mathrm{c}$ & $0.38 \mathrm{~d}$ \\
\hline $\mathrm{GA}_{4+7}$ & $0.59 \mathrm{~d}$ & $0.68 \mathrm{~d}$ & $0.08 \mathrm{a}$ & $733 c$ & $40.9 \mathrm{~b}$ & $0.38 \mathrm{~d}$ \\
\hline $\mathrm{BA}+\mathrm{GA}_{4+7}$ & $0.71 \mathrm{e}$ & $0.80 \mathrm{e}$ & $0.09 \mathrm{a}$ & $783 \mathrm{~d}$ & $42.5 \mathrm{a}$ & $0.38 \mathrm{~d}$ \\
\hline NAA & $0.82 \mathrm{e}$ & $0.89 \mathrm{e}$ & $0.09 \mathrm{a}$ & $917 \mathrm{e}$ & $15.4 \mathrm{f}$ & $2.27 \mathrm{a}$ \\
\hline
\end{tabular}

${ }^{x} \mathrm{GR}$ applied dilute 22,25 Sept. and 12 Oct. 1982.

${ }^{y}$ LR determined 21 Nov. 1982. Each mean contains nine observations.

${ }^{\times} \mathrm{CL}$ and $\mathrm{XN}$ content determined 2 Nov. 1982. Each mean contains 27 observations.

wMean separation within columns by Duncan's mutiple range test $(P=0.05)$.

diness of 'Johnson Elberta' flower buds.

\begin{tabular}{|c|c|c|c|}
\hline Treatment & Year & Test date & $\begin{array}{l}\text { Decrease }(>) \text { or increase }(<) \\
\text { in hardiness }\left(\mathrm{T}_{50},{ }^{\circ} \mathrm{C}\right)\end{array}$ \\
\hline Defoliation & $\begin{array}{l}198-84 \\
1984-85 \\
1985-86 \\
1986-87 \\
1982\end{array}$ & $\begin{array}{r}23 \text { Nov. } \\
21 \text { Dec. } \\
11 \text { Nov. } \\
7 \text { Dec. } \\
23 \text { Dec. } \\
3 \text { Jan. } \\
25 \text { Jan. } \\
10 \text { Mar. } \\
25 \text { Mar. } \\
21 \text { Nov. } \\
19 \text { Nov. } \\
20 \text { Dec. } \\
22 \text { Nov. } \\
20 \text { Dec. } \\
17 \text { Nov. } \\
19 \text { Dec. } \\
15 \text { Sept. } \\
29 \text { Sept. } \\
14 \text { Oct. } \\
28 \text { Oct. } \\
15 \text { Nov. } \\
30 \text { Nov. }\end{array}$ & $\begin{array}{c}<3.1^{*} \\
<2.3^{*} \\
<1.7^{*} \\
<2.8^{*} \\
<2.7^{*} \\
<2.7^{*} \\
<3.1^{*} \\
<2.5^{*} \\
<2.5^{*} \\
<3.1^{*} \\
<3.4^{*} \\
<2.1^{*} \\
0.5^{2} \\
0.3^{*} \\
<1.8^{*} \\
1.0 \\
>2.2^{*} \\
>6.2^{*} \\
>3.5^{*} \\
>2.8^{*} \\
0.9^{\circ} \\
1.0^{2}\end{array}$ \\
\hline
\end{tabular}

( $(100 \mu \mathrm{M})$ Treatment dates in Table 1.

${ }^{\gamma} 1$ Sept.

*Significant hardiness increase (NAA) or decrease (defoliation) compared with the control. Mean separation by Duncan's multiple range test $(P=0.05)$. Means of three $\mathrm{T}_{50}$ determinations from 200 to 400 observations each.

'Redhaven' peach in $\mathrm{CO}$ was not affected by NAA treatment (data not shown). Similarly, hardiness of flower buds of 'Montmorency' tart cherry in MT during a natural freeze was unaffected by the NAA treatments. In each case, however, NAA had significantly delayed leaf abscission.

\section{Effect of NAA on bud and flower size}

NAA-treated 'Johnson Elberta' flowers were significantly smaller in December than flowers from trees treated with $\mathrm{GA}_{3}$ or water + surfactant controls (Table 5). The entire flower bud was significantly shorter but not narrower than control buds. $\mathrm{GA}_{3}$ treatment did not affect bud length or width compared with the control.
Table 4. Flower bud hardiness $\left(T_{50}\right)$ on 23 Nov. 1983 on both sides of control and 100 and $1000 \mu \mathrm{M}$ NAA-treated 'Johnson Elberta' trees treated on one side on 20, 23, and 26 Sept. Hardiness at lower concentrations ( 1 and $10 \mu \mathrm{M})$ was not significantly different from the control.

\begin{tabular}{clc}
\hline $\begin{array}{c}\text { NAA concn } \\
(\mu \mathrm{M})\end{array}$ & Side & $\begin{array}{c}\text { Hardiness } \mathrm{T}_{50}{ }^{\mathrm{z}} \\
\left({ }^{\circ} \mathrm{C}\right)\end{array}$ \\
\hline 0 & Untreated & $-21.8 \mathrm{a}$ \\
& Treatedy & $-21.8 \mathrm{a}$ \\
100 & Untreated & $-23.9 \mathrm{~b}$ \\
& Treated & $-24.7 \mathrm{~b}$ \\
1000 & Untreated & $-24.6 \mathrm{~b}$ \\
& Treated & $-25.5 \mathrm{~b}$ \\
\hline
\end{tabular}

"Mean separation within column by Duncan's multiple range test, $P=0.05$. Each mean contains three $\mathrm{T}_{50}$ values, each obtained from 300 to 400 single bud observations.

YTriton X77, $1 \mathrm{ml} \cdot$ liter $^{-1}$, no NAA.

Table 5. Effects of autumn applications (21, 24, 27 Sept. 1984) of NAA and $\mathrm{GA}_{3}$ on flower and bud size of 'Johnson Elberta' peach trees. UT, measured 19 Dec. 1984.

\begin{tabular}{llcc}
\hline \hline & \multicolumn{3}{c}{ Bud size $(\mathrm{mm})$} \\
\cline { 2 - 4 } Measurement & Control & $\mathrm{NAA}^{\mathrm{z}}$ & $\mathrm{GA}_{3}{ }^{\mathrm{z}}$ \\
\hline Bud length & $4.76 \mathrm{~b}^{\mathrm{y}}$ & $4.28 \mathrm{a}$ & $5.11 \mathrm{~b}$ \\
Bud width & $2.60 \mathrm{a}$ & $2.43 \mathrm{a}$ & $2.75 \mathrm{a}$ \\
Flower length & $1.63 \mathrm{~b}$ & $1.23 \mathrm{a}$ & $1.67 \mathrm{~b}$ \\
Flower width & $1.03 \mathrm{~b}$ & $0.86 \mathrm{a}$ & $1.06 \mathrm{~b}$ \\
\hline
\end{tabular}

${ }^{x}$ Growth regulators applied at $100 \mu \mathrm{M}$.

yMean separation in rows by Duncan's multiple range test, $P=0.05$. Each mean contains 30 observations.

\section{Effect of NAA on endodormancy extension}

All GRs extended the 'Johnson Elberta' dormancy period significantly in the order: NAA $1000 \mu \mathrm{M}=\mathrm{NAA} 100 \mu \mathrm{M}>$ $\mathrm{BA}+\mathrm{GA}_{4+7}>\mathrm{GA}_{4+7}=\mathrm{GA}_{3}>$ control (Table 6). Correlation analysis of the 1982 data indicated that $87 \%$ of the variation in endodormancy extension in peach was due to increased LR (data not shown). In contrast, tart cherry bloom in MT was accelerated after $100 \mu \mathrm{M}$ NAA induced LR. Treated trees had an average of $77 \%$ open flowers on 8 May 1986 compared with $44 \%$ open flowers on controls. Thus, peaches and tart cherries differ in their endodormancy responses to NAA. 
Table 6. Endodormancy extension of 'Johnson Elberta' peach terminal vegetative buds due to GR. Shoots collected at weekly intervals during the winter were soaked in $\mathrm{GA}_{3}$ at 5 to $500 \mathrm{mg} \cdot \mathrm{liter}^{-1}$ for $1 \mathrm{~h}$ and forced in a growth chamber. Endodormancy was considered terminated when the $\mathrm{GA}_{3}$ effect disappeared.

\begin{tabular}{lc}
\hline \hline Treatment & $\begin{array}{c}\text { Days from } 9 \text { Dec. } \\
\text { to end of endodormancy }\end{array}$ \\
\hline Control & $27 \mathrm{a}$ \\
$\mathrm{GA}_{3}$ & $43 \mathrm{~b}$ \\
$\mathrm{GA}_{4+7}$ & $43 \mathrm{~b}$ \\
$\mathrm{BA}+\mathrm{GA}_{4+7}$ & $52 \mathrm{c}$ \\
$\mathrm{NAA}$ & $64 \mathrm{~d}$ \\
$\mathrm{NAA}(1000 \mu \mathrm{M})$ & $70 \mathrm{~d}$ \\
\hline
\end{tabular}

${ }^{2} \mathrm{GR}$ treatments applied at $100 \mu \mathrm{M}$ unless otherwise indicated on 22 , 25 Sept. and 12 Oct. 1982.

${ }^{\mathrm{y}}$ Mean separation by Duncan's multiple range test, $\boldsymbol{P}=0.05$. Each mean contains 15 observations.

\section{Discussion}

Deciduous leaf senescence may be induced by nutrient, water, or light deficiencies, short days, or low temperatures. In temperate-zone fruit trees, senescence may be due to a combination of these effects on aging leaves in late summer and early autumn. Endogenous growth promoters in shoots of orchard species reach minima in early summer, while abscisic acid (ABA) increases until about the time of leaf fall (Salisbury and Ross, 1978.) ABA is strongly associated with senescence. Stomatal closure, mediated by ABA, preceeds senescence, and ABAinduced changes in cyclic photophosphorylation are probably also involved (Thimann, 1980). In aged apple (Malus domestics, Borkh.) leaves, exogenous ABA-induced acceleration of senescence can be delayed by NAA, BA, or $\mathrm{GA}_{4+7}$ (S. D. S., unpublished). Thus, in some plants, stress-induced ABA synthesis accelerates senescence, while various GRs can counteract its effects. In our studies, NAA was the most effective GR in delaying leaf senescence as measured by $\mathrm{LR}, \mathrm{PF}$, and $\mathrm{XN}$ content. Chlorophyll content, however, decreased more rapidly in NAA treatments than in others. It could be argued that NAA did not delay senescence but only increased $\mathrm{XN}$ content and delayed abscission zone maturity.

'Johnson Elberta' peach flower bud hardiness increased when leaf fall was delayed by NAA treatments. No comparable hardiness increase was found in 'Montmorency' cherry in MT or 'Redhaven' peach in CO. Specific climatological conditions in UT, such as daylength and thermoperiod, may have triggered the additional hardiness development.

A translocatable cold-hardiness promoter produced in leaves under hardening conditions has been postulated by Fuchigami et al. (1971). Our results provide evidence for the existence of a similar promoter in 'Johnson Elberta' peach. NAA treatment on one side of the tree affected the hardiness of the entire tree, although the treatment prolonged leaf retention only on the treated side. If the effect were simply due to photosynthate production or enhanced sink strength, differences should have been found between the treated and untreated sides. Furthermore, temperature' and light conditions during the period would not result in large photosynthate reserves.

The effect of defoliation on 'Gleason Elberta' peach flower bud hardiness was documented by Walser (1975) and Walser et al. (1981). Late-summer defoliation inhibited flower bud hardening significantly and reduced endodormancy intensity. The presence of leaves in greenhouse maintained warm conditions (>15C) suppressed the development of endodormancy in ter- minal leaf buds of 'Gleason Elberta' peach. Subsequently, when temperatures in the greenhouse were decreased to a minimum of $1.5 \mathrm{C}$ after leaf fall, dormancy intensity increased beyond the control and the endodormant period was significantly extended. Our results agree with those of Walser, indicating that defoliation inhibited flower bud hardening, and that prolonged LR in the autumn delayed endodorrnancy release.

NAA treatment resulted in smaller flowers and flower buds than in the controls. Enhanced fall leaf activity may have required more metabolizes and, therefore, may have been a relatively stronger sink than flowers on the NAA-treated trees. The hardening effect of NAA treatment may have been due to decreased flower size. However, GA application also increased hardiness somewhat (data not shown) without significantly affecting flower size.

Xanthophyll concentration in NAA-treated trees increased significantly over the control treatment, indicating that some metabolic pathways were preferentially stimulated. An increase. in XNs might also favor their conversion to ABA.

Auxin applications in late summer (Hitchcock and Zimmerman, 1943) and ethylene applications in the autumn (Dennis, 1976; Gianfagna, 1989; Gianfagna et al., 1986) delay flowering in peach. Flower bud differentiation was delayed 15 days and bud fresh weight was about half that of the controls after treatment with $120 \mathrm{mg}$ ethephon/liter on 24 Sept. (Crisosto et al., 1989). Auxins, including NAA, stimulate ethylene production (Sembdner et al., 1980), and ethylene, as well as NAA, affects partitioning of assimilates between vegetative and reproductive organs in the autumn. Ethylene-induced bloom delay may be due to influences on flower ontogeny during endodormancy (Crisosto et al., 1989), or on springtime phenology, since Gianfagna et al. (1986) indicate that temperatures during anthesis affect ethylene-induced bloom delay. Ethylene-induced bloom delay may be the result of extended endodormancy, but the critical studies have not been done.

All GR applications that delayed leaf fall also delayed endodorrnancy release in 'Johnson Elberta' peach. Extended endodormancy in cold climates does not always result in delayed bloom. Endodormancy release has a low temperature rangebetween -2 to $12 \mathrm{C}$-with an optimum around 5 to $7 \mathrm{C}$. In cold climates temperatures often remain below the threshold for flower bud growth and development during the winter season. This condition allows continued chilling in the absence of suitable temperatures for growth. During this time the chilling requirement is completed, and while there is observable bloom delay in forced material there is no comparative bloom delay under field conditions. In warmer climates, limited periods of low temperatures result in slower endodorrnancy release, and growing temperatures occur earlier. This produces observable bloom delay. In our study, peach endodormancy in UT was completed by 5 Jan. 1983. Hormonally extended endodormancy lasted 37 and 43 days longer in the trees treated with $1000 \mu \mathrm{M}$ and 100 $\mu \mathrm{M}$ NAA, respectively, than in the controls. However, no bloom delay was observed in the field, because substantial amounts of chilling occurred in January and February when temperatures were not conducive to growth.

In summary, NAA and other GRs applied in early fall caused LR and delayed leaf senescence in peach and cherry. NAA-treated tree leaves had lower CL but higher XN content than leaves of trees treated with GAs or BA + GAs. NAA-treated 'Johnson Elberta' peach tree flower buds were more cold hardy than those on control trees. Trees unilaterally treated with NAA hardened to cold equally on both sides and to the same extent as trees treated 
in their entirety. A translocatable cold hardiness factor appears to be present. Endodormancy extension was correlated with LR in 'Johnson Elberta' peach. However, bloom delay did not occur due to high chilling temperature accumulations before the occurrence of temperatures above the growth threshold.

\section{Literature Cited}

Bruinsma, J. 1963. The quantitative analysis of chlorophylls $a$ and $b$ in plant extracts. Photochem. Photobiol. 2:241-249.

Butt, V.S. and C.J. Lamb. 1981. Oxygenates and the metabolism of plant products, p. 627-665. In: P.K. Stumpf and E.E. Corm (eds.). The biochemistry of plants, a comprehensive treatise. vol. 7. Secondary plant products. Academic, New York.

Crisosto, C. H., P.B. Lombard, and L.H. Fuchigami. 1989. Fall ethephon delays bloom in 'Redhaven' peach by delaying flower differentiation and development during dormancy. J. Amer. Soc. Hort, Sci. 114:881-884.

Dennis, F. G., Jr. 1976. Trials of ethephon and other growth regulators for delaying bloom in tree fruits. J. Amer. Soc. Hort. Sci. 101:241245.

Edgerton, L.J. 1966. Some effects of gibberellin and growth retardants on bud development and cold hardiness of peach. Proc. Amer. Soc. Hort. Sci. 88:197-203.

Fuchigami, L, H., D.R. Evert, and C.J. Weiser. 1971. A translocatable cold hardiness promoter. Plant PhysioI. 47:164-167.

Gianfagna, T.J. 1989. Chemical control with ethephon of bud dormancy, cold hardiness, and time of bloom in peach trees. Plant Growth Regulat. Soc. Amer. Quart. 17:39-47.

Gianfagna, T. J., R. Marini, and S. Rachmiel. 1986. Effect of ethephon and $\mathrm{GA}_{3}$ on time of flowering in peach. HortScience 21:69-70.

Hatch, A. H. and D. R. Walker. 1969. Rest intensity of dorrnant peach and apricot leaf buds as influenced by temperature, cold hardiness and respiration. J. Amer. Soc. Hort. Sci. 93:304-307.

Hitchcock, A.E. and P.W. Zimmerman. 1943. Summer sprays with potassium a-naphthalene acetate retard opening of buds on fruit trees. Proc. Amer. Soc. Hort. Sci. 42:141-145.
Holubowicz, T. 1982. The effect of defoliation and the age of the leaves on development of frost resistance of fruit shoots. XXI IntL Hort. Congr. 1:1008(Abstr.)

Leopold, A.C. 1955. Auxins and plant growth. Univ. of California Press, Berkeley.

Nissila, P.C. and L.H. Fuchigami. 1978. Xylem water potential and electrical impedance ratios as measures of vegetative maturity in Red-osier dogwood (Comus stolonifera Michx.) J. Amer. Soc. Hort. Sci. 103:708-709.

Osborne, D.J. and H.M. Hallaway. 1960. Auxin control of protein levels in detached autumn leaves. Nature (London) 188:240-241.

Osborne, D.J. and H.M. Hallaway. 1964. The auxin 2,4D as a regulator of protein synthesis and senescence in detached leaves of Prunus. New Phytol. 63:334-336.

Proebsting, E. L., Jr. and H.H Mills. 1964. Gibberellin-induced hardiness responses in Elberta peach flower buds. Proc. Amer. Soc. Hort. Sci. 85:135-140.

Proebsting, E. L., Jr. and H.H. Mills. 1974. Time of gibberellin application determines hardiness response of 'Bing' cherry buds and wood. J. Amer. Soc. Hort. Sci. 99:464-466.

Proebsting, E. L., Jr. and H.H. Mills. 1976. Ethephon increases cold hardiness of sweet cherry. J. Amer. Soc. Hort. Sci. 101:31-33.

Salisbury, F.B. and C.W. Ross. 1978. Plant physiology, Wadsworth Publishing, Belmont, Calif. p. 328.

Sembdner, G., D. Gross, H.W. Liebisch, and G. Schneider. 1980 Biosynthesis and metabolism of plant hormones, p. 281-444. In: A. Pirson and M.H. Zimmerman (eds.). Encyclopedia of plant physiology 9. Springer-Verlag, New York.

Thimann, K.V. 1980. The senescence of leaves, p. 85-116. In: K.V. Thimann (cd.). Senescence in plants. CRC, Boca Raton, Fla.

Walser, R.H. 1975. Influence of environment and cultural practices on rest, cold hardiness, and abscisic acid concentration of 'Gleason Elberta' peach buds. PhD Diss., Utah State Univ., Logan.

Walser, R. D., D.R. Walker, and S.D. Seeley. 1981. Effect of temperature, fall defoliation, and gibberellic acid on the rest period of peach leaf buds. J. Amer. Soc. Hort. Sci. 106:91-94. 